\title{
Online measurements of water-soluble organic acids in the gas and aerosol phase from the photooxidation of 1,3,5-trimethylbenzene
}

\author{
A. P. Praplan ${ }^{1,{ }^{*}, \text { K. Hegyi-Gaeggeler }}{ }^{1}$, P. Barmet ${ }^{1}$, L. Pfaffenberger ${ }^{1}$, J. Dommen ${ }^{1}$, and U. Baltensperger ${ }^{1}$ \\ ${ }^{1}$ Laboratory of Atmospheric Chemistry, Paul Scherrer Institute, Villigen PSI, Switzerland \\ *now at: Department of Physics, University of Helsinki, Helsinki, Finland \\ Correspondence to: J. Dommen (josef.dommen@psi.ch)
}

Received: 25 November 2013 - Published in Atmos. Chem. Phys. Discuss.: 13 January 2014

Revised: 17 May 2014 - Accepted: 13 June 2014 - Published: 26 August 2014

\begin{abstract}
The formation of organic acids during photooxidation of 1,3,5-trimethylbenzene (TMB) in the presence of $\mathrm{NO}_{\mathrm{x}}$ was investigated with an online ion chromatography (IC) instrument coupled to a mass spectrometer (MS) at the Paul Scherrer Institute's smog chamber. Gas and aerosol phase were both sampled. Molecular formulas were attributed to 12 compounds with the help of high-resolution MS data from filter extracts (two compounds in the gas phase only, two in the aerosol phase only and eight in both). Seven of those species could be identified: formic acid, acetic acid, glycolic acid, butanoic acid, pyruvic acid, lactic acid and methylmaleic acid. While the organic acid fraction present in the aerosol phase does not strongly depend on the precursor concentration (6 to $20 \%$ ), the presence of $\mathrm{SO}_{2}$ reduces this amount to less than $3 \%$ for both high and low precursor concentration scenarios. A large amount of acetic acid was injected during one experiment after aerosol formation, but no increase of acetic acid particle concentration could be observed. This indicates that the unexpected presence of volatile organic acids in the particle phase might not be due to partitioning effects, but to reactive uptake or to sampling artefact.
\end{abstract}

\section{Introduction}

Aromatic compounds are ring-containing volatile organic compounds (VOCs) emitted into the atmosphere by fuel combustion and evaporation, where they are oxidised by hydroxyl radicals $(\mathrm{OH})$ or nitrate radicals $\left(\mathrm{NO}_{3}\right)$. They play a major role in urban areas and can represent $13-44 \%$ of the total hydrocarbon mass in the atmosphere (Calvert, 2002;
Dommen et al., 2003; Molina et al., 2007; Vega et al., 2011). As a result of their oxidation, products with lower volatility are formed, which contribute to the formation of secondary organic aerosol (SOA; Kroll and Seinfeld, 2008; Hallquist et al., 2009).

The organic fraction of the atmospheric aerosol, to which SOA contributes, is a complex mixture of many different compounds (Kanakidou et al., 2005; Williams et al., 2007). Decesari et al. (2000) reported that $20-70 \%$ of these compounds are water-soluble organic compounds (WSOCs). However, only $10 \%$ of this water-soluble organic fraction of the aerosol can typically be chemically identified (Saxena and Hildemann, 1996).

Organic acids represent an important class of atmospheric chemical compounds (Chebbi and Carlier, 1996) and a large fraction of WSOCs, and they can be directly emitted into the atmosphere by traffic (Kawamura et al., 2000), biogenic emissions (Servant et al., 1991) and biomass burning (Gaeggeler et al., 2008).

They can also be produced through chemical reactions of Criegee intermediates produced by ozonolysis of alkenes: either via their unimolecular isomerisation or via their bimolecular stabilisation with water (Calvert and Madronich, 1987; Horie et al., 1994). Other reactions have also been suggested as sources of organic acids, such as peroxyacyl nitrate (PAN) decomposition (Surratt et al., 2009), or the reaction of peroxyacetyl radicals $\left(\mathrm{R}(\mathrm{O}) \mathrm{O}_{2}\right)$ with hydroperoxy $\left(\mathrm{HO}_{2}\right)$ or alkylperoxy $\left(\mathrm{RO}_{2}\right)$ radicals, respectively (Madronich et al., 1990). Additionally, aqueous oxidation in cloud droplets is an important source of organic acids in the atmosphere (Altieri et al., 2008; Lim et al., 2005). 
Measurement of organic acids is a challenging task. Offline methods are labour-intensive and offer usually low time resolution, while available online methods with low detection limits can provide high time resolution, such as chemical ionisation mass spectrometry (Veres et al., 2011; Le Breton et al., 2012; Paulot et al., 2009; de Gouw and Warneke, 2007). However, both offline and online methods are prone to artefacts. Samples on a filter can evaporate, or other species can condense on it, for instance. Some online methods, such as proton-transfer-reaction mass spectrometry (PTR-MS) can be sensitive to fragmentation. Additionally, low resolution of the mass spectra may hinder the separation of different species, making data analysis and interpretation more difficult, but high-resolution techniques (such as time-of-flight MS) have been developed recently to improve this (Graus et al., 2010; Jokinen et al., 2012). The ion chromatography (IC) method presented here allows water-soluble organic acids (as well as nitrite, nitrate and sulfate) to be separated prior to detection. By using a quadrupole mass spectrometer (MS) as an additional detector, further separation based on molar mass can be performed on co-eluting peaks.

Fisseha et al. (2004) identified 20 different acids formed during 1,3,5-trimethylbenzene (TMB) photooxidation experiments at the Paul Scherrer Institute smog chamber. The main goal of this work is to investigate further organic acids formation and evolution over time during TMB photooxidation (including their partitioning behaviour) under different experimental conditions.

\section{Experimental}

\subsection{PSI smog chamber}

A detailed description of the Paul Scherrer Institute smog chamber and its standard instrumentation can be found elsewhere (Paulsen et al., 2005). Experiments are carried out in a $27 \mathrm{~m}^{3}$ transparent fluoroethylene propylene (FEP) bag placed in a temperature-controlled housing $\left(\sim 20^{\circ} \mathrm{C}\right)$. The chamber is first humidified to a relative humidity $(\mathrm{RH})$ of approximately $50 \%$ before injecting nitrogen oxides $\left(\mathrm{NO}_{\mathrm{x}}\right)$. A known amount of liquid TMB is then evaporated in a heated glass sampling bulb $\left(80^{\circ} \mathrm{C}\right)$ and flushed with pure air into the chamber approximately $30 \mathrm{~min}$ before the lamps are switched on, to allow homogeneous mixing of all gas phase compounds. To simulate the solar spectrum, four $4 \mathrm{~kW}$ xenon-arc lamps are used (light spectrum $>280 \mathrm{~nm}$ ) and directed parallel to the chamber walls.

Their UV emissions below $300 \mathrm{~nm}$ are filtered by a borosilicate glass filter ("selected white float glass", SWF, Präzisions Glas \& Optik GmbH, Germany) and the $\mathrm{NO}_{2}$ photolysis rate is $10^{-3} \mathrm{~s}^{-1}$. In selected experiments, supplementary black lights (eighty $100 \mathrm{~W}$ tubes, light spectrum between 320 and $400 \mathrm{~nm}$, Cleo Performance) were used to increase the ultraviolet (UV) light intensity, increasing the $\mathrm{NO}_{2}$ photolysis rate to $1.5 \times 10^{-2} \mathrm{~s}^{-1}$. Light is reflected by aluminium plates covering the inside of the housing walls of the chamber and is responsible for $\mathrm{OH}$ formation, by ozone $\left(\mathrm{O}_{3}\right)$ photolysis. For the representative experiments described here (Table 1), the ratio VOC: $\mathrm{NO}_{\mathrm{x}}$ was set to 2 . For some experiments, approximately $2 \mathrm{ppbv}$ of sulfur dioxide $\left(\mathrm{SO}_{2}\right)$ were also injected into the chamber in order to enhance the nucleation rate, to increase the SOA particle number concentration and to reduce vapour wall losses.

The standard instrumentation of the smog chamber consists of an $\mathrm{O}_{3}$ monitor (Environics model S300) and a chemiluminescence trace gas $\mathrm{NO}-\mathrm{NO}_{2}-\mathrm{NO}_{\mathrm{x}}$ analyser $42 \mathrm{C}$ (Thermo Environmental Instruments Inc., USA), a butanol condensation particle counter (CPC, model 3025, TSI Inc., USA) with a cut-off of $3 \mathrm{~nm}$ and a scanning mobility particle sizer (SMPS) for particles with mobility diameter between 14 and $698 \mathrm{~nm}$. The SMPS system consists of a long column differential mobility analyser (model 3071, TSI Inc., USA) and a CPC (model 3010, TSI Inc., USA). Additionally, a PTR-MS (IONICON Analytik GmbH, Austria) for TMB measurements and an IC coupled to a MS for the selective analysis of organic acids (Sect. 2.2) were used. The PTRMS was calibrated with a mixture of gas standards containing TMB and the IC/MS system was calibrated with organic acid standards (see Sect. 2.5).

\subsection{Ion chromatography system}

The sampling of the gas and particle phase for the IC system was done with a wet effluent diffusion denuder (WEDD) and an aerosol collector (AC), respectively (Takeuchi et al., 2004, 2005). The WEDD part is connected with a Teflon ${ }^{\circledR}$ inlet to the smog chamber. It consists of two parallel cellulose acetate membranes between which continuous sampling from the smog chamber gas phase occurs. Purified water flows on the other side of the membranes, allowing gases to dissolve. The AC part is connected by a silcosteel ${ }^{\circledR}$ inlet to the smog chamber. An activated charcoal denuder and a WEDD are placed upward of the sampling device, to remove the gas phase compounds. Figure 1 shows that after placing a filter on the sampling line, the measured aerosol concentrations return to background level. No breakthrough of the gas phase to the aerosol collector occurs, even with high precursor concentrations. The AC consists of a small chamber, the bottom of which is covered by a filter paper placed on a hydrophilic filter. Water is introduced into this chamber through a capillary having its tip close to the nozzle where the airflow enters. A fine mist is formed, which condenses on the filter where the soluble compounds of the particles are dissolved.

Fisseha et al. (2004) estimated the collection efficiency of the WEDD to be 75 and $85 \%$ for formic and acetic acid, respectively. Therefore, a correction factor has been applied to the reported concentration, assuming an averaged $80 \%$ collection efficiency. For the AC, mass collection efficiency is 
Table 1. Description of the presented representative 1,3,5-trimethylbenzene (TMB) photooxidation experiments.

\begin{tabular}{|c|c|c|c|c|c|c|}
\hline Date & \multicolumn{4}{|c|}{ Nominal concentrations (ppbv) } & $\mathrm{RH}$ & Comments \\
\hline 10 Jul 2009 & 1200 & 300 & 300 & - & $\sim 50 \%$ & injection of acetic acid $(500 \mu \mathrm{L})$ after approximately $6 \mathrm{~h}$ of photooxidation \\
\hline 10 Dec 2010 & 1200 & 300 & 300 & - & $\sim 50 \%$ & \\
\hline 11 Apr 2011 & 1200 & 300 & 300 & 2 & $\sim 50 \%$ & \\
\hline
\end{tabular}

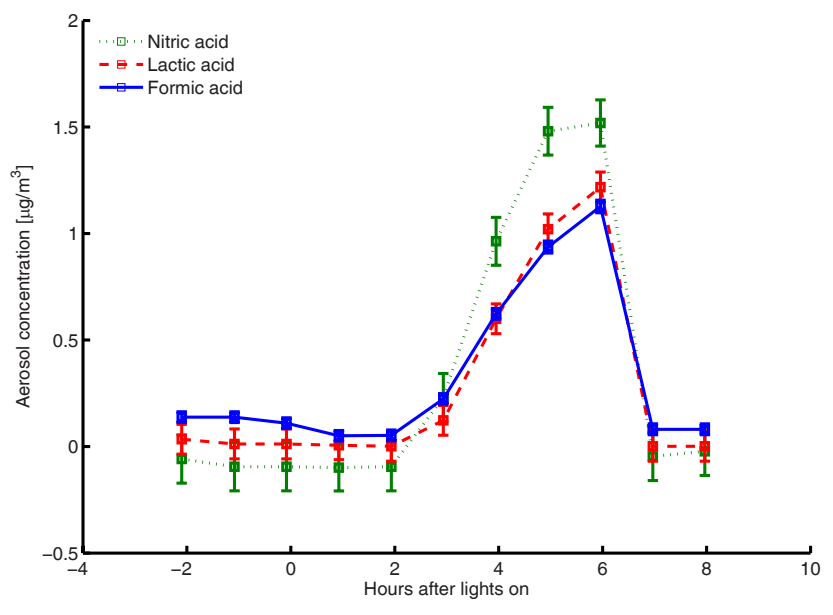

Figure 1. No breakthrough of the gas phase to the aerosol collector (AC) was observed when a filter was placed $6 \mathrm{~h}$ after lights on in the aerosol sampling line during a 1200 ppbv 1,3,5-trimethylbenzene (TMB) photooxidation experiment.

over $95 \%$ so that the aerosol phase concentrations reported here have not been corrected.

Effluents from both sampling devices pass through concentration columns (TAC-LP1, Dionex) where the (organic and inorganic) anions are retained. Those samples are then eluted alternately to the guard and analytical columns (NG1 and AS11-HC, Dionex) for separation with a flow rate of $0.25 \mathrm{ml} \mathrm{min}^{-1}$. The eluent consists of a hydroxide anion $\left(\mathrm{OH}^{-}\right)$gradient, generated by an Eluent Generator (EG40, Dionex) from a potassium cation $\left(\mathrm{K}^{+}\right)$electrolyte reservoir with the following sequence: $0 \mathrm{~min} 0.95 \mathrm{mM} \mathrm{OH}^{-}, 3 \mathrm{~min}$ $0.95 \mathrm{mM} \mathrm{OH}^{-}, 18 \mathrm{~min} 12 \mathrm{mM} \mathrm{OH}^{-}, 22 \mathrm{~min} 60 \mathrm{mM} \mathrm{OH}^{-}$, $24 \mathrm{~min} 60 \mathrm{mM} \mathrm{OH}^{-}, 24.1 \mathrm{~min} 0.95 \mathrm{mM} \mathrm{OH}^{-}$and $29 \mathrm{~min}$ $0.95 \mathrm{mM} \mathrm{OH}^{-}$. After elution, the $\mathrm{OH}^{-}$are suppressed by an anion self-regenerating suppressor (ASRS $3002 \mathrm{~mm}$, Dionex). The analytes are detected as deprotonated species by a conductivity detector (CD) first and, after negative electrospray ionisation ((-)ESI, capillary voltage: $-1.5 \mathrm{kV})$, by a quadrupole MS (MSQ, Thermo Finnigan) with unit mass resolution.
The retention time (RT) of the analytes depends on the strength of the ion exchange with the analytical column. Deprotonated organic acids with only one carboxylic functional group will elute earlier, followed by acids with two and three carboxylic functional groups at later RTs.

Calibration is performed by direct injection of aqueous multi-compound standards of different concentrations onto the analytical column. Non-linear least squares regression of a power function $\left(y=a x^{b}+c\right)$ is used as calibration curve for the MS, in order to take into account the slight curvature of some calibration curves (Fig. 2), as suggested by Kirkup and Mulholland (2004). This is due to the formation of dimers and aggregates with water during ESI, especially at higher concentrations, and possibly varying fragmentation (Grossert et al., 2005) at different concentration levels. Limits of detection (expressed in ng) have been defined from the calibration curves and converted to $\mathrm{ng} \mathrm{m}^{-3}$ according to the experimental sampling flows of WEDD and AC for each experiment. Typical limits of detection for organic acids ranged from 0.12 to $5.1 \mathrm{ng} \mathrm{m}^{-3}$.

Due to the presence of numerous unknown compounds, it is not possible to tune the instrument for each individual substance to prevent the formation of dimers, for example. If a molecular formula could be assigned to an unknown compound, a surrogate compound with a similar degree of unsaturation (expected similar functionalisation, see Sect. 2.3) and a similar mass was used for calibration.

\subsection{High-resolution MS}

The high-resolution Orbitrap-MS instrument of the Functional Genomics Centre Zurich is described in detail elsewhere (Olsen et al., 2007). The high mass accuracy (2 ppm) allows deduction of the accurate elemental composition of the detected organic acids. From the obtained chemical formula, it is then possible to compute their degree of unsaturation (DU), also known as "double bond equivalent", using Eq. (1), where $\mathrm{C}, \mathrm{H}$ and $\mathrm{N}$ represent the number of carbon, hydrogen and nitrogen atoms, respectively:

$\mathrm{DU}=(\mathrm{C}+1)-\frac{(\mathrm{H}-\mathrm{N})}{2}$ 


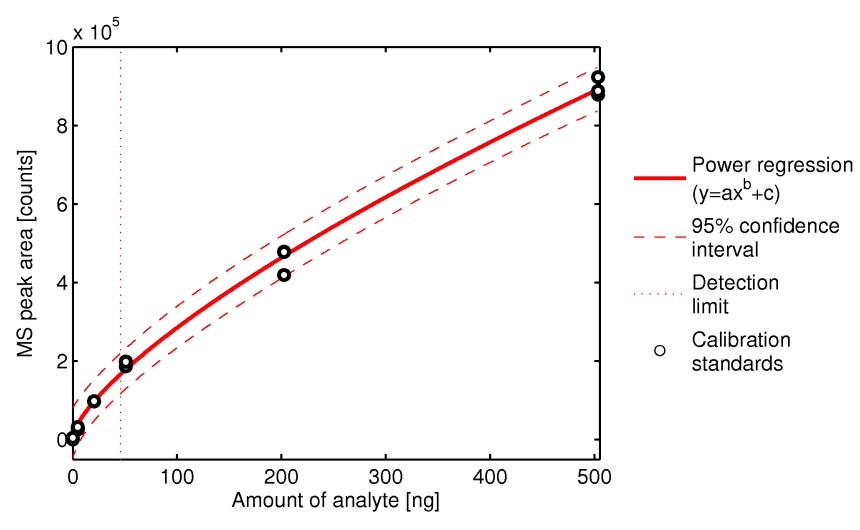

Figure 2. Example of IC/MS calibration (methylmaleic acid).

This provides the number of double bonds or rings of a compound and can help for the structure elucidation of an unknown compound: for example, monocarboxylic acids with DU $>1$ contain a ring structure or a carbon-carbon double bond if $\mathrm{O}=2$ ( $\mathrm{O}$ represents the number of oxygen atoms) or may contain one or more ketone or aldehyde functionalities if $\mathrm{O}>2$. The deductions are similar for the dicarboxylic acids with $\mathrm{DU}>2$. Furthermore, if $\mathrm{O}>2$ for monocarboxylic acids with $\mathrm{DU}=1$ or if $\mathrm{O}>4$ for dicarboxylic acids with $\mathrm{DU}=2$, the oxygen atoms that are not in the carboxylic functional groups are most likely present as alcohol functional groups. In this study, $\mathrm{N}=0$ is assumed as no even $\mathrm{m} / \mathrm{z}$ was detected and it is unlikely that species with two nitrogen atoms are detected but none with only one $\mathrm{N}$-atom.

For these measurements, SOA particles were collected on Teflon filters and extracted with water. The solutions were finally directly injected into the instrument through a capillary and ionised by electrospray. The measurements ranged from 50 to 700 amu.

\subsection{Partitioning theory}

One important feature of the WEDD/AC-IC/MS setup presented is that it is possible to measure almost simultaneously gas phase and aerosol concentrations of the organic acids. Therefore, partitioning coefficients $K_{\mathrm{p}}\left(\mathrm{m}^{3} \mu \mathrm{g}^{-1}\right)$ can be determined experimentally by Eq. (2) and estimated theoretically by Eq. (3), using partitioning theory (Pankow, 1994a, b):

$$
\begin{aligned}
K_{\mathrm{p}, i} & =\frac{F_{i}}{f_{\mathrm{m}} \cdot \mathrm{TSP} \cdot A_{i}} \\
K_{\mathrm{p}, i} & =\frac{f_{\mathrm{m}} \cdot 760 \cdot R \cdot T}{\mathrm{MW}_{\mathrm{m}} \cdot p_{\mathrm{L}}^{0} \cdot \xi \cdot 10^{6}}
\end{aligned}
$$

TSP $\left(\mu \mathrm{g} \mathrm{m}^{-3}\right)$ is the total suspended particulate mass and $f_{\mathrm{m}}$ represents its absorbing mass fraction (assumed to be unity for SOA). $F_{i}$ and $A_{i}\left(\mu \mathrm{g} \mathrm{m}^{-3}\right)$ are the measured aerosol and gas phase concentrations of species $i$, respectively. $R$ is the ideal gas constant $\left(8.2 \times 10^{-5} \mathrm{~m}^{3}\right.$ atm mol $\left.{ }^{-1} \mathrm{~K}^{-1}\right), T[\mathrm{~K}]$ is the temperature, $M W_{\mathrm{m}}$ is the mean molar mass of the absorbing material and is assumed here to be $130 \mathrm{~g} \mathrm{~mol}^{-1}$. $\xi$ is the activity coefficient of the species in the condensed phase (assumed to be unity) and $p_{\mathrm{L}}^{0}$ (Torr) is the saturation vapour pressure. Estimates for $p_{L}^{0}$ can be derived from structure-based methods ${ }^{1}$ (Stein and Brown, 1994; Myrdal and Yalkowsky, 1997; Nannoolal et al., 2004; Moller et al., 2008; Nannoolal et al., 2008; Compernolle et al., 2011). The partitioning of organic acids is also influenced by their dissociation in the particle phase which depends on $\mathrm{pH}$ $\left(-\log \left[\mathrm{H}^{+}\right]\right)$. Acid dissociation is not considered for $K_{\mathrm{p}}$ values derived from Eq. (3) which is representative for a very acidic aerosol. Thus for less acidic or neutralised aerosols an effective partitioning coefficient ( $\left.K_{\mathrm{p} \text {,eff }}\right)$ needs to be calculated using dissociation constants of acids $\left(K_{\mathrm{a}}\right)$, determined for aqueous solutions, according to

$K_{\mathrm{p}, \text { eff }, i}=K_{\mathrm{p}, i}\left(1+\frac{K_{\mathrm{a}}}{\left[\mathrm{H}^{+}\right]}\right)$

However, since TMB SOA is only slightly hygroscopic (Duplissy et al., 2011), the fraction of water in the particles is only minor.

\subsection{Chemicals}

Water used for this work was delivered by a Milli-Q water purification system and had a resistivity of $18 \mathrm{M} \Omega \mathrm{cm}$.

Standards were available for formic acid (85\%), acetic acid $(\geq 99.8 \%)$, glycolic acid $(\geq 99.0 \%)$, pyruvic acid $(\geq 98 \%)$, butanoic acid $(\geq 95 \%)$, lactic acid $(\geq 95 \%)$, methylmaleic acid ( $\geq 98 \%)$, methacrylic acid ( $\geq 99 \%)$, 3butenoic acid ( $\geq 97 \%)$ and trans-2-butenoic acid $(\geq 98 \%)$.

TMB was supplied by Fluka $(\geq 99.5 \%)$. Gas cylinders were provided by Carbagas: NO2.8 in $\mathrm{N}_{2} 5.0, \mathrm{NO}_{2} 1.8$ in synthetic air 5.0 and $\mathrm{SO}_{2} 3.8$ in $\mathrm{N}_{2}$ 5.0.

\section{Results and discussion}

\subsection{TMB photooxidation}

Figure 3 presents the measured mixing ratios of $\mathrm{NO}, \mathrm{NO}_{2}$ and $\mathrm{O}_{3}$. Ozone photolysis triggers the formation of $\mathrm{OH}$ radicals, which oxidise TMB.

Note that $\mathrm{NO}_{3}$ do not play a role in TMB photooxidation under these experimental conditions; $\mathrm{NO}_{3}$ is rapidly photolysed to $\mathrm{NO}$ or $\mathrm{NO}_{2}$. Oxidation products are formed and when $\mathrm{NO}$ has reached low levels, the formation of $\mathrm{O}_{3}$ strongly increases. This happens much faster with the stronger black lights. Figure $4 \mathrm{~b}$ shows the $\mathrm{OH}$ concentration derived from TMB reacted measured with PTR-MS (Fig. 4a), as TMB

\footnotetext{
${ }^{1}$ http://www.aim.env.uea.ac.uk/aim/ddbst/pcalc_main.php (EAIM) and http://tropo.aeronomie.be/models/evaporation_run.htm (EVAPORATION)
} 


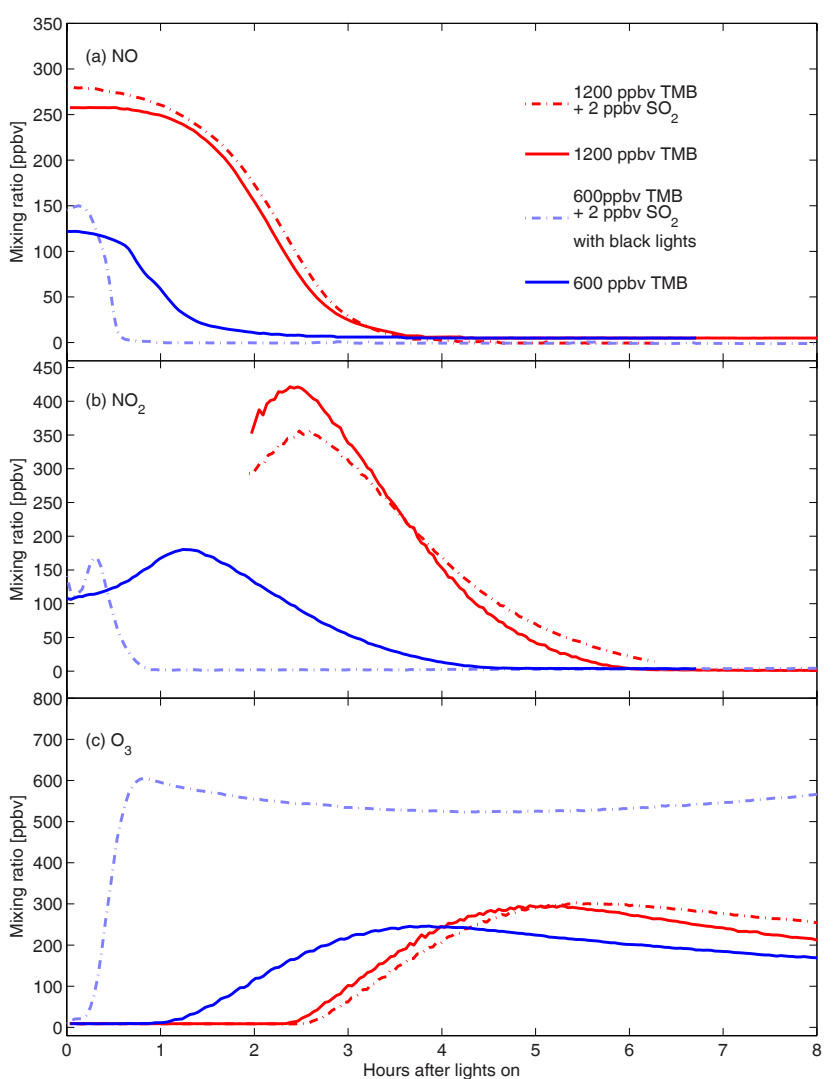

Figure 3. Nitrogen oxide $(\mathrm{NO}, \mathbf{a})$, nitrogen dioxide $\left(\mathrm{NO}_{2}, \mathbf{b}\right)$ and ozone $\left(\mathrm{O}_{3}, \mathbf{c}\right)$ mixing ratios for the different experiments. High concentration experiments: red; low concentration experiments: blue; without $\mathrm{SO}_{2}$ : solid lines; with $\mathrm{SO}_{2}$ : dashed lines. $\mathrm{NO}_{2}$ data are missing at the beginning of the high concentration experiments, due to an instrumental limitation.

does not react with any other oxidant. As expected, the values using black lights are higher: ca. $2.5 \times 10^{6} \mathrm{~cm}^{-3}$ with a peak of $7 \times 10^{6} \mathrm{~cm}^{-3}$ at the beginning of the experiment, compared to values between $10^{5}$ and $10^{6} \mathrm{~cm}^{-3}$ for the other experiments. All values are in the lower range of daytime $\mathrm{OH}$ concentration in the troposphere. The low concentration experiment without $\mathrm{SO}_{2}$ or black lights is not displayed as no PTR-MS data are available for this experiment. However, as this experiment was performed at similar $\mathrm{RH}$ and with the same conditions as the ones with high TMB concentration, the $\mathrm{OH}$ concentration is expected to be similar.

\subsection{SOA formation}

Physical aerosol properties from four experiments are shown in Fig. 5 where low concentration experiments are coloured in blue and high concentration experiments in red. The lowest panel of Fig. 5 presents the aerosol mass concentration measured by the SMPS assuming a particle density $\rho_{\mathrm{p}}$ of $1.4 \mathrm{~g} \mathrm{~cm}^{-3}$ (Alfarra et al., 2006).

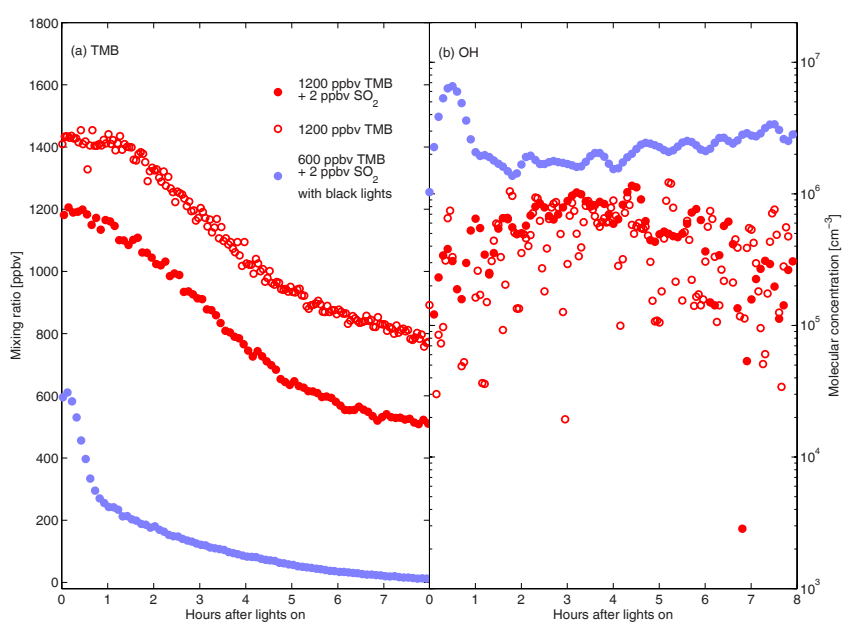

Figure 4. 1,3,5-Trimethylbenzene (TMB, a) and derived hydroxyl radicals $(\mathrm{OH}, \mathbf{b})$ concentrations for the different experiments. Filled symbols: with $\mathrm{SO}_{2}$; open symbols: without $\mathrm{SO}_{2}$; red: high conc.; blue: low conc.

Particles sufficiently large to be detected are formed when the NO mixing ratio becomes low in the system, similarly to earlier observations (Ng et al., 2007; Wyche et al., 2009). The SOA particles reached mobility diameters up to $\sim 700 \mathrm{~nm}$ during the photooxidation of 1200 ppbv TMB in the absence of $\mathrm{SO}_{2}$. This is on the edge of the SMPS measurement range for singly charged particles. Therefore, the particle number size distribution was recovered from the raw signal of the doubly charged particles, which appeared at smaller diameters within the measurement range, using a custom-made data inversion routine, which works in a similar way as the standard SMPS data inversion (Hagen and Alofs, 1983). The very narrow size distribution and thus the clear separation between singly and multiple charged particles allowed us to use this approach.

In the absence of $\mathrm{SO}_{2}$ (Fig. 5, solid lines), more SOA is produced at higher precursor concentration than with a lower precursor concentration but its formation starts later and the final diameter of the particles formed is larger. From the CPC data (not shown), particles larger than $3 \mathrm{~nm}$ can be observed after approximately $3.2 \mathrm{~h}$ after lights on during the experiments with $1200 \mathrm{ppbv}$ TMB while in the case with $600 \mathrm{ppbv}$ nucleation occurs already after $2 \mathrm{~h}$ of photooxidation (Wyche et al., 2009).

The presence of $\mathrm{SO}_{2}$ increases the nucleation rate as described in Metzger et al. (2010): it is possible to observe particles in the CPC $(>3 \mathrm{~nm})$ already after 1 hour of photooxidation (1200 ppbv TMB). The slightly higher final aerosol mass concentration produced in the presence of $\mathrm{SO}_{2}$ during the high concentration experiments is probably explained by the earlier particle formation, resulting in lower vapour wall losses of low-volatility oxidation products. 


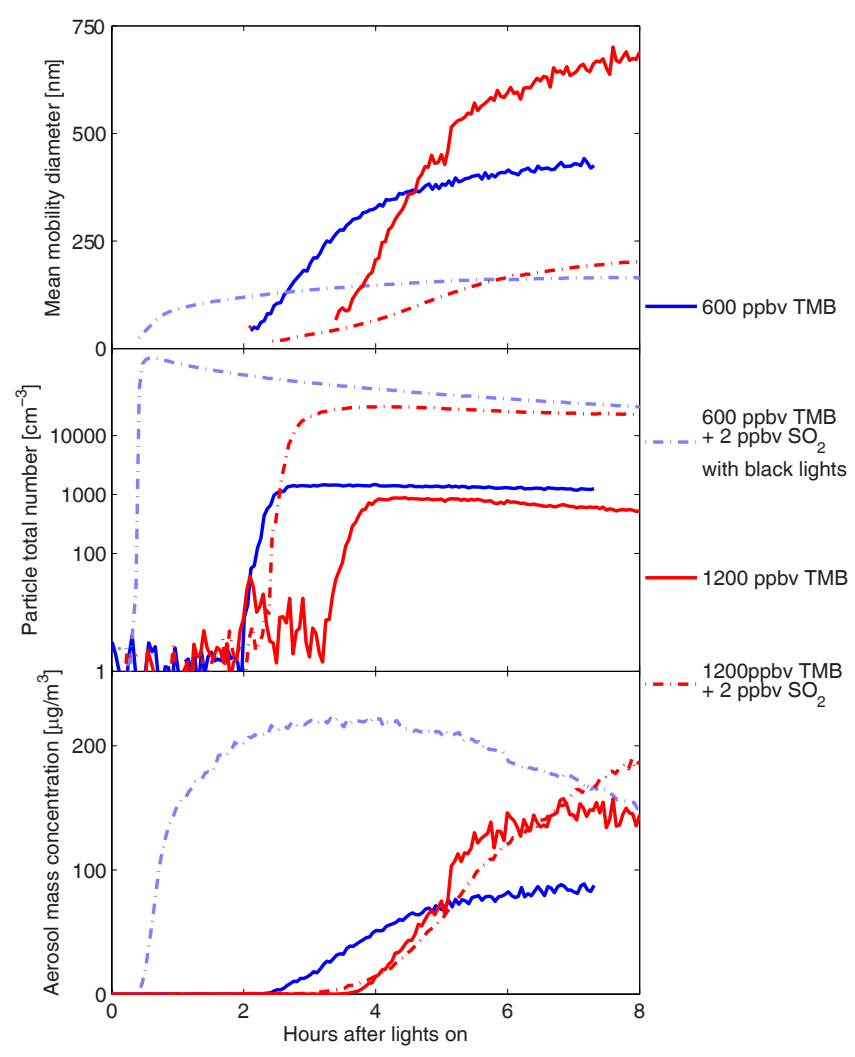

Figure 5. Mean diameter, total number concentration and aerosol mass concentration (assuming $\rho_{\mathrm{p}}=1.4 \mathrm{~g} \mathrm{~cm}^{-3}$ ) from the scanning mobility particle sizer (SMPS) measurements. These data are not corrected for wall losses. High concentration experiments: red; low concentration experiments: blue; without $\mathrm{SO}_{2}$ : solid lines; with $\mathrm{SO}_{2}$ : dashed lines.

Black lights increase the nucleation rate the most, due to the higher $\mathrm{OH}$ concentration and faster oxidation of the gaseous compounds. When the xenon-arc lamps are switched on together with additional black lights, 12 min of photooxidation are sufficient to detect particles with the CPC in the presence of $\mathrm{SO}_{2}$. The maximum aerosol mass produced is higher than for other experiments due to the higher amount of TMB reacted and the dramatic reduction of the vapour wall losses in the early nucleation stage.

\subsection{Identified organic acids}

Table 2 gives an overview of the organic acids detected during TMB photooxidation. Twenty-five mass chromatograms showed one or more peaks. The corresponding masses are listed in Table 2 and a chemical formula could be attributed to 12 of them with the help of the high-resolution MS data. Chemical formulas containing only one oxygen atom were not considered, as carboxylic acids contain at least two oxygen atoms. Seven compounds could be unambiguously identified: formic acid, acetic acid, glycolic acid, butanoic acid, pyruvic acid, lactic acid and methylmaleic acid.
Fisseha et al. (2004) did not identify glycolic acid and butanoic acid, but reported detection of oxalic acid, malonic acid, succinic acid, malic acid and citric acid, which were not detected in the present work. The only unknown compounds detected in both studies are the ones with nominal mass 178 , 190 and 234.

Sato et al. (2012) could also identify pyruvic acid as well as other organic acids with liquid chromatography coupled to a time-of-flight MS. They found several peaks for the (deprotonated) masses: $127\left(\mathrm{C}_{6} \mathrm{H}_{7} \mathrm{O}_{3}^{-}\right), 161\left(\mathrm{C}_{6} \mathrm{H}_{9} \mathrm{O}_{5}^{-}\right)$, $215\left(\mathrm{C}_{9} \mathrm{H}_{11} \mathrm{O}_{6}^{-}\right)$and $233\left(\mathrm{C}_{9} \mathrm{H}_{13} \mathrm{O}_{7}^{-}\right)$as well as single peaks of the (deprotonated) masses $189\left(\mathrm{C}_{6} \mathrm{H}_{7} \mathrm{O}_{3}^{-}\right)$and 217 $\left(\mathrm{C}_{9} \mathrm{H}_{13} \mathrm{O}_{6}^{-}\right)$, each corresponding to an identified peak in this study.

While several possible elemental compositions are reported in Table 2 for these compounds, as it was not possible to unambiguously identify which peaks in the highresolution spectra corresponded to the unit mass observed with IC/MS, Sato et al. (2012) report unique elemental composition for each reported mass. They also report other masses, which were not found in this work, either because they do not have a carboxylic acid functional group, or because the sensitivity of our method was not sufficient to detect them.

The Master Chemical Mechanism (MCM, Jenkin et al., 2003; Saunders et al., 2003) contains a degradation scheme for TMB of which Table 3 presents the expected organic acids. Of those, only acetic acid and pyruvic acid could be identified in our experiments. Also acids with nominal masses 128, 144 and 160 were detected, but it was not possible to assign the species proposed by MCM to IC peaks, mainly because more than one peak was found for each of these unit masses and their structure could not be determined. Formation mechanisms for the other identified organic acids are not discussed here, as they are mainly low molar mass compounds and can originate from various oxidation pathways as for acetic acid and pyruvic acid. It is also known that the mechanism of later generation products is not well understood (Metzger et al., 2008).

Two of the compounds for which a chemical formula could be attributed have a DU equal to 4 (DU of TMB), while 10 have a lower DU. This indicates that fragmentation and double bond opening reactions happen on top of the functionalisation with one or two carboxylic groups (1 DU for each group).

Figures 6 and 7 show the concentration profiles in the gas and the aerosol phase, respectively, for the main measured species: formic acid, acetic acid, glycolic acid, butanoic acid, pyruvic acid, lactic acid, methylmaleic acid and an unknown dicarboxylic acid with molar mass $234 \mathrm{~g} \mathrm{~mol}^{-1}$ (M234). In the aerosol phase the measured concentrations are mostly lower than $1 \mu \mathrm{g} \mathrm{m}^{-3}$, except for M234. Some of these species were close to the detection limit of the method and therefore gaps can be observed in the plots. Methylmaleic acid is a 
Table 2. Organic acids detected with WEDD/AC-IC/MS during 1,3,5-trimethylbenzene (TMB) photooxidation.

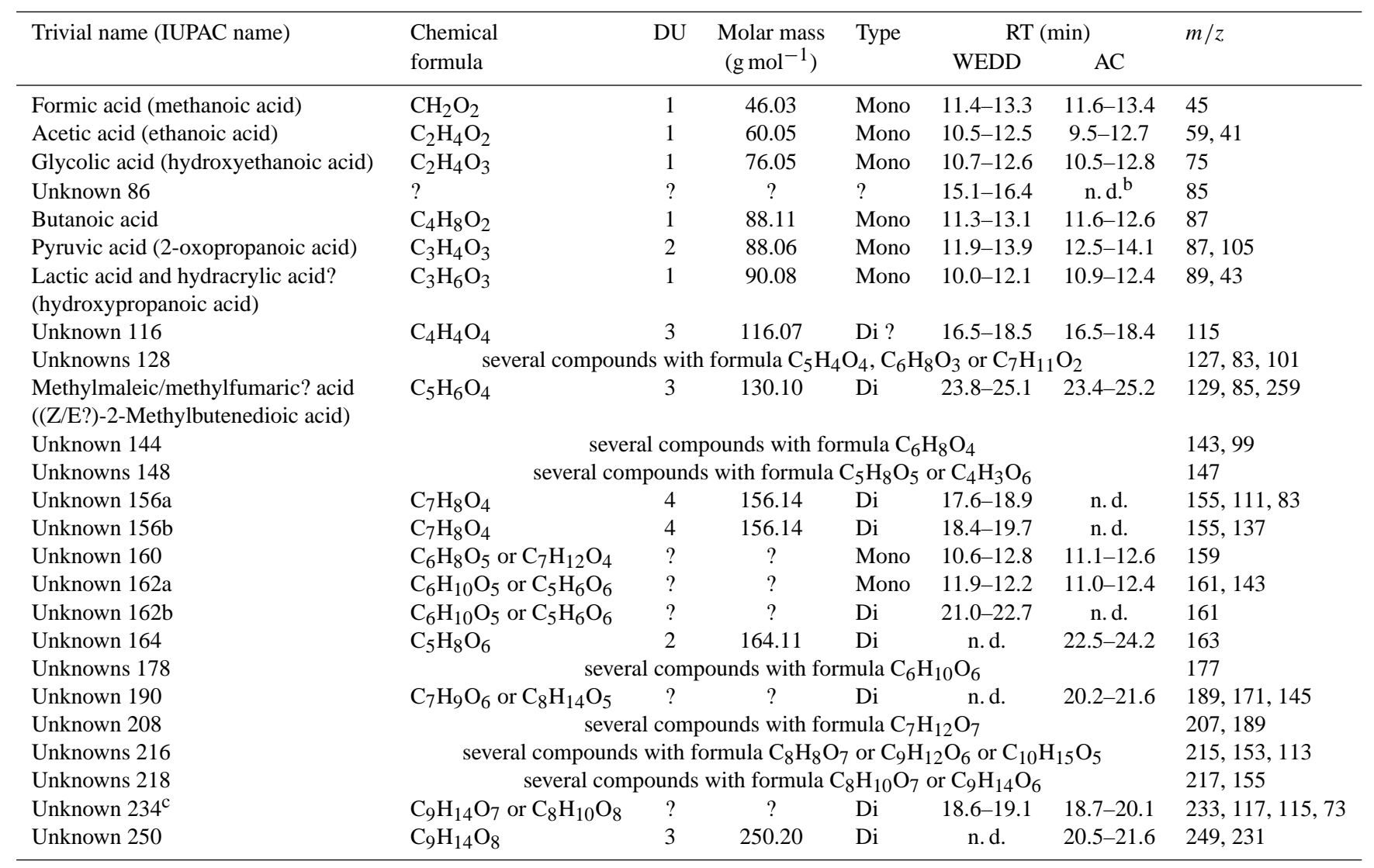

a Butanoic acid as surrogate.

b Not detected.

${ }^{\mathrm{c}}$ Methylmaleic acid as surrogate.

Table 3. Expected organic acids and related species from the Master Chemical Mechanism (MCM) model for the oxidation of 1,3,5trimethylbenzene (TMB).

\begin{tabular}{lllr}
\hline MCM name & IUPAC name (trivial name) & Formula & Molar mass \\
\hline CH3CO2H & Ethanoic acid (acetic acid) & $\mathrm{C}_{2} \mathrm{H}_{4} \mathrm{O}_{2}$ & 60.05 \\
$\mathrm{HCOCO} 2 \mathrm{H}$ & Oxoethanoic acid (glyoxylic acid) & $\mathrm{C}_{2} \mathrm{H}_{2} \mathrm{O}_{3}$ & 74.04 \\
$\mathrm{CH} 3 \mathrm{COCO} 2 \mathrm{H}$ & Oxopropanoic acid (pyruvic acid) & $\mathrm{C}_{3} \mathrm{H}_{4} \mathrm{O}_{3}$ & 88.06 \\
$\mathrm{C} 5 \mathrm{CODBCO} 2 \mathrm{H}$ & 2-Methyl-4-oxo-pent-2-enoic acid & $\mathrm{C}_{6} \mathrm{H}_{8} \mathrm{O}_{3}$ & 128.13 \\
EPXMKTCO2H & 3-Acetyl-2-methyloxirane-2-carboxylic acid & $\mathrm{C}_{6} \mathrm{H}_{8} \mathrm{O}_{4}$ & 144.13 \\
C23O3MCO2H & 2-((2-oxopropanoyl)oxy)propanoic acid & $\mathrm{C}_{6} \mathrm{H}_{8} \mathrm{O}_{5}$ & 160.12 \\
TMBCO2H & 3,5-Dimethylbenzoic acid & $\mathrm{C}_{9} \mathrm{H}_{10} \mathrm{O}_{2}$ & 150.17 \\
TM135MUO2H & (Z)-2-Methyl-3-(4-oxopent-2-en-2-yl)oxirane-2-carboxylic acid & $\mathrm{C}_{9} \mathrm{H}_{12} \mathrm{O}_{4}$ & 184.19 \\
MMALANHY* & 3-Methylfuran-2,5-dione (methylmaleic anhydride) & $\mathrm{C}_{5} \mathrm{H}_{4} \mathrm{O}_{3}$ & 112.08 \\
\hline
\end{tabular}

* Detected as methylmaleic acid.

dicarboxylic acid and is not expected with such high concentrations in the gas phase (without being detected accordingly in the aerosol phase at the same time). Most probably it is formed from the expected methylmaleic anhydride in the sampling device, as observed by Sato et al. (2007) for maleic anhydride, succinic anhydride, and citraconic anhydride from toluene photooxidation. This indicates that other detected species may possibly be formed by similar artefacts from other compounds. Butanoic acid, pyruvic acid and methylmaleic acid gas phase concentrations show a precursor concentration dependence, confirming that they are products of TMB oxidation.

The glycolic acid concentration, on the other hand, does not seem to show such a dependence, but because the 


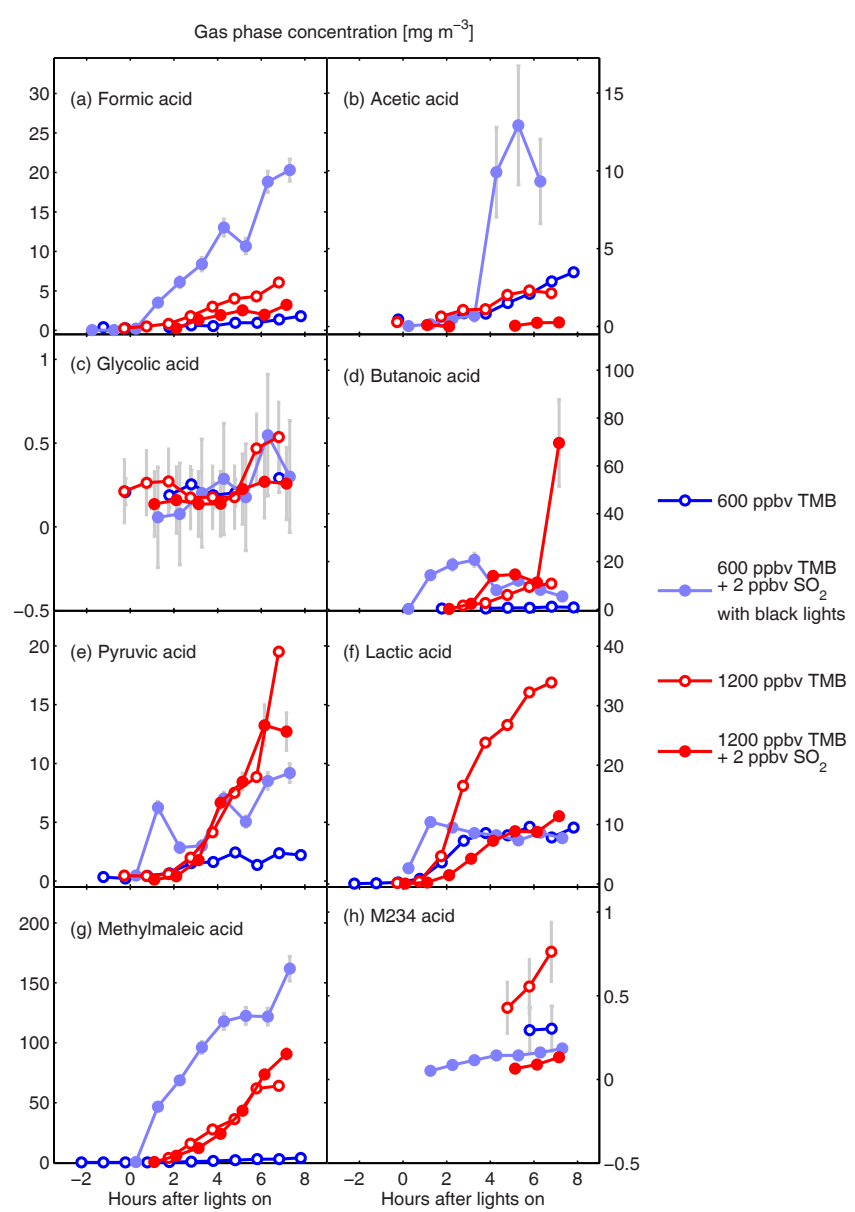

Figure 6. Gas phase concentration profiles (in $\mu \mathrm{g} \mathrm{m}^{-3}$ ) of eight measured organic acids. Filled symbols: with $\mathrm{SO}_{2}$; open symbols: without $\mathrm{SO}_{2}$; red: high conc.; blue: low conc. Error bars in grey are derived from calibration curves and sampling flow uncertainties.

concentration remains small and close to background levels in both gas and aerosol phase, no conclusion can be drawn on glycolic acid production dependence on TMB levels.

For lactic acid, a marked difference is seen comparing the two 1200 ppbv TMB experiments. The presence of $\mathrm{SO}_{2}$ decreases its concentration by roughly a factor of 3 . A similar effect is observed for acetic acid, lactic acid and M234. The presence of $\mathrm{SO}_{2}$ decreases the aerosol concentration for these species, as they are likely formed in the gas phase.

Recent studies show that $\mathrm{SO}_{2}$ reacts much faster with Criegee radicals than previously reported $\left(10^{-13}\right.$ $10^{-11} \mathrm{~cm}^{3} \mathrm{~s}^{-1}$; Welz et al., 2012; Mauldin III et al., 2012; Boy et al., 2013). The differences in the experiments with and without $\mathrm{SO}_{2}$ could be explained by reaction of a precursor Criegee radical with that species, hindering the formation of these acids. This is an indication that these acids would form via ozonolysis of primary oxidation products of TMB, while other acids are generated from TMB oxidation by $\mathrm{OH}$.

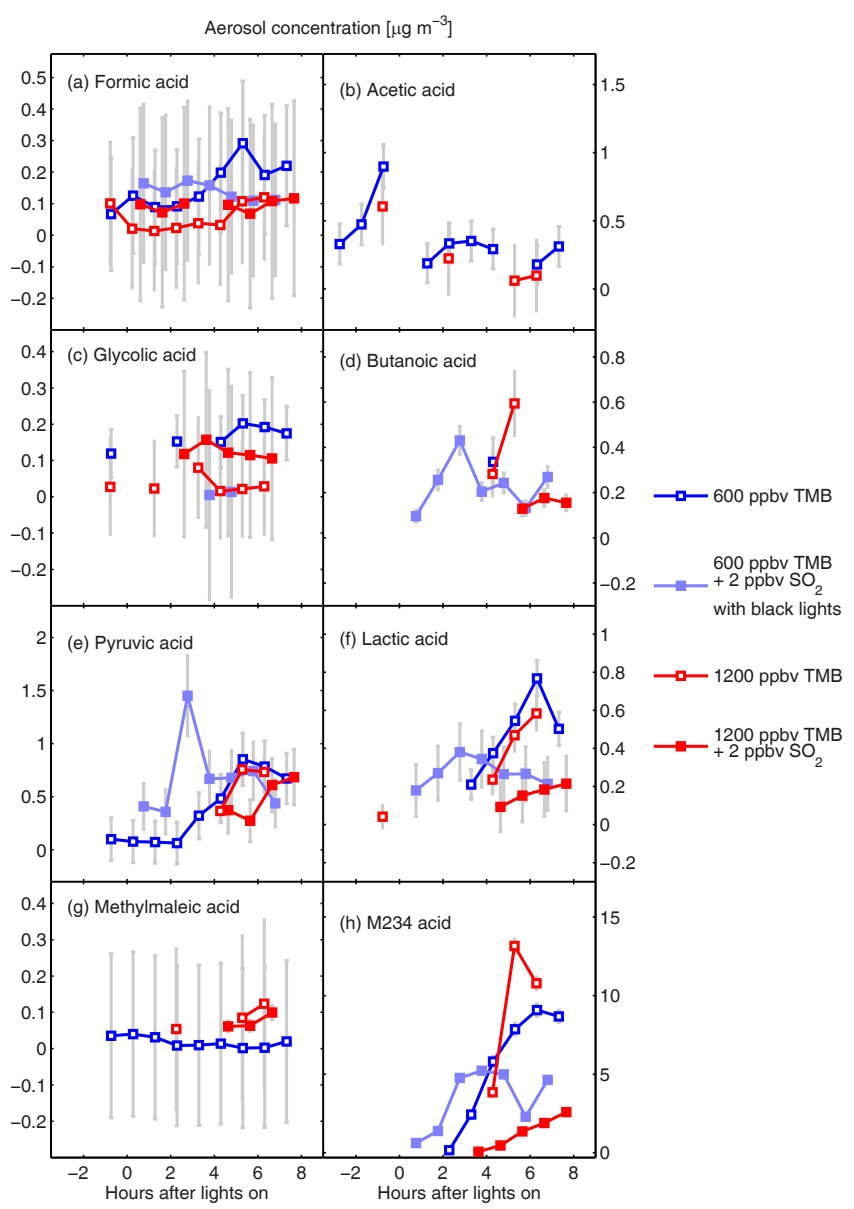

Figure 7. Aerosol concentration profiles (in $\mu \mathrm{g} \mathrm{m}^{-3}$ ) of eight measured organic acids. See Fig. 6 for symbol explanation.

However, $\mathrm{SO}_{2}$ would be able to compete with water vapour only if the reaction rate between Criegee intermediates and water vapour is at the low end of the measurement range found in the literature $\left(10^{-15}-10^{-19} \mathrm{~cm}^{3} \mathrm{~s}^{-1}\right)$, due to the orders of magnitude different concentrations of $\mathrm{SO}_{2}$ and water $\left(5 \times 10^{10} \mathrm{~cm}^{-3}\right.$ and $3 \times 10^{17} \mathrm{~cm}^{-3}$ respectively). Because of the large uncertainties of these reaction rates, it is not possible to totally neglect this reaction path.

Due to the different aerosol mass concentrations produced, acid fractions were computed by dividing the particle bound acid concentration by the aerosol mass concentration measured with the SMPS. Figure $8 b$ and d show a drop of the acid fraction of the main acids below $5 \%$ if $\mathrm{SO}_{2}$ is present, while its lower limit lies between 6 and $20 \%$ in the absence of $\mathrm{SO}_{2}$ (Fig. 8a and c). This is expected, because less partitioning of the organic acids occurs, due to the more acidic aerosol in the presence of $\mathrm{H}_{2} \mathrm{SO}_{4}$ formed from $\mathrm{SO}_{2}$ oxidation.

The compound M234 in Table 2 merits particular attention. It is the most abundant organic acid of the aerosol phase. It could be detected in small amounts in the gas 


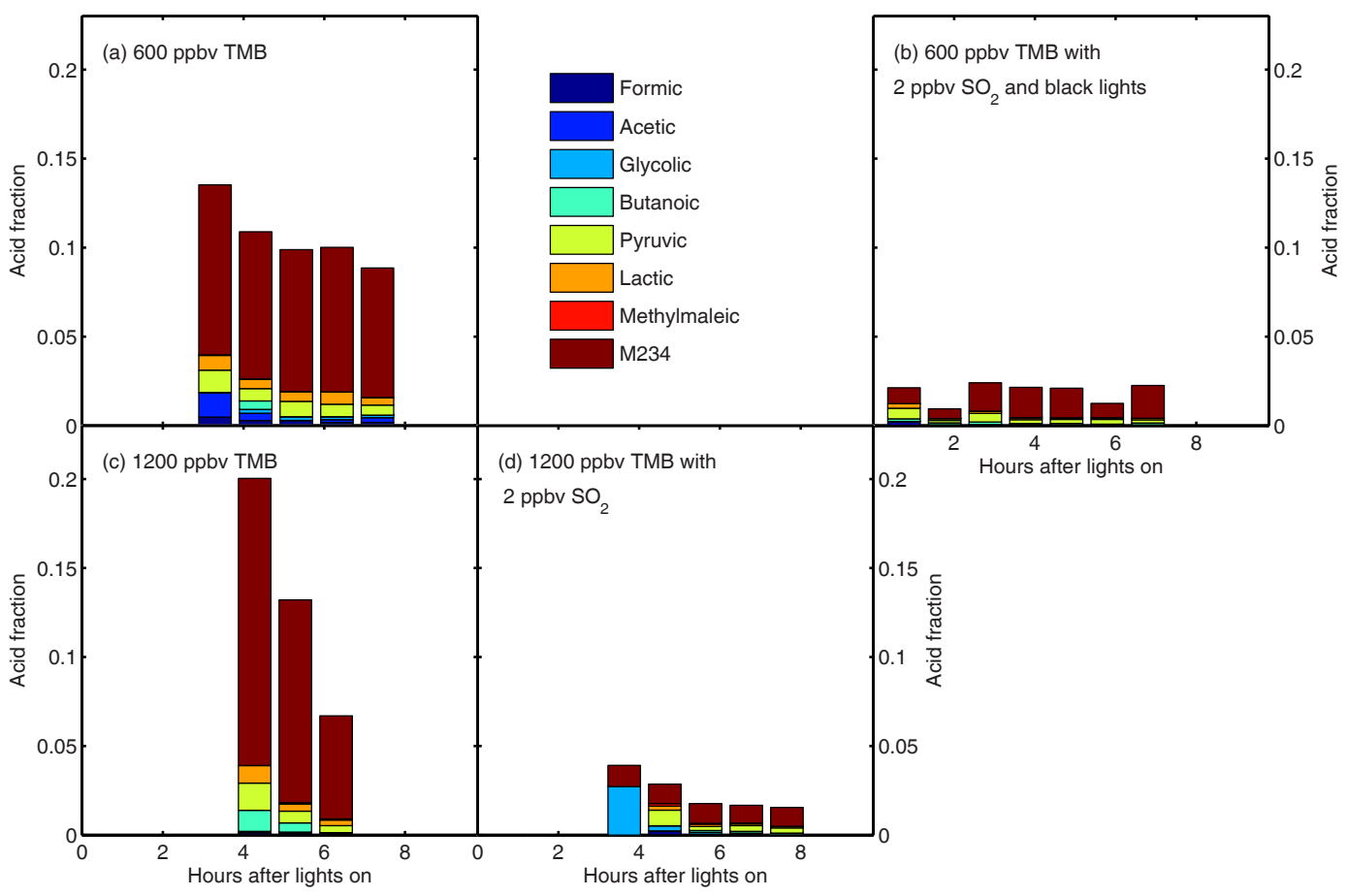

Figure 8. Stacked aerosol concentrations of the main detected organic acids normalised to the aerosol mass concentration (from SMPS) for the different experimental conditions.

phase and is potentially important for the SOA formation. Sato et al. (2012) report three compounds with this mass and the chemical formula $\mathrm{C}_{9} \mathrm{H}_{14} \mathrm{O}_{7}$, while we could identify only one peak with this mass and assigned it to a dicarboxylic acid, based on its retention time (18.6-20.1 min). It is possible that the IC/MS instrumentation used in this study either is not sensitive enough to detect the other species, or that these cannot be separated by the chromatographic method. However, the results presented here suggests that at least one of the compounds identified by Sato et al. (2012) should be a dicarboxylic acid. If the other compounds cannot be separated, it could be that all three are dicarboxylic acids. It is also possible that two of the compounds detected by Sato et al. (2012) do not contain a carboxylic functional group and cannot be detected by the IC/MS method used. However, if they do have at least one such functional group, their concentration could be below the detection limit of our instrumentation.

Another compound from Table 2 requires some discussion: the unknown compound with molar mass $86(\mathrm{~m} / z 85$ in IC/MS). There is a limited amount of organic acids with this molar mass: methacrylic acid, 3-butenoic acid and trans/cis2-butenoic acid. The RT of the unknown compound with molar mass 86 listed in Table 2 is longer than the ones of methacrylic acid, 3-butenoic acid and trans-2-butenoic acid, though. Standards of these compounds were available for comparison. Because no larger mass was detected for the same peak at this RT, the possibility that this compound would be a fragment of a larger one has been ruled out. This leaves the possibility that $c i s$-2-butenoic acid was detected, however this could not be proven due to the lack of a standard. In that case, one possible explanation for the longer RT, compared to the other organic acids with the same molar mass, could be its somewhat more compact shape, due to its cis configuration, allowing it to remain somewhat longer on the analytical column.

Due to the remaining uncertainties, more work is needed to identify the chemical structure of the numerous compounds that are formed during photooxidation of TMB. A combination of different analytical techniques like gas or liquid chromatography with high-resolution mass spectrometry would be necessary.

\subsection{Partitioning coefficients, $K_{\mathrm{p}}$}

Figure 9 depicts the time-dependent $K_{\mathrm{p}}$ values for the previously discussed species. Due to the alternating gas phase and aerosol measurements, linear interpolation or extrapolation was performed to estimate the corresponding aerosol or gas phase concentration for a given time. Nevertheless, due to some measurements very close to the detection limit, especially in the aerosol phase, some points could not be estimated. In most cases, the experimental $K_{\mathrm{p}}$ values for the different conditions are more or less stable during the experiments. Only for glycolic acid and methylmaleic acid a decreasing trend is observed in the earlier stages of the 


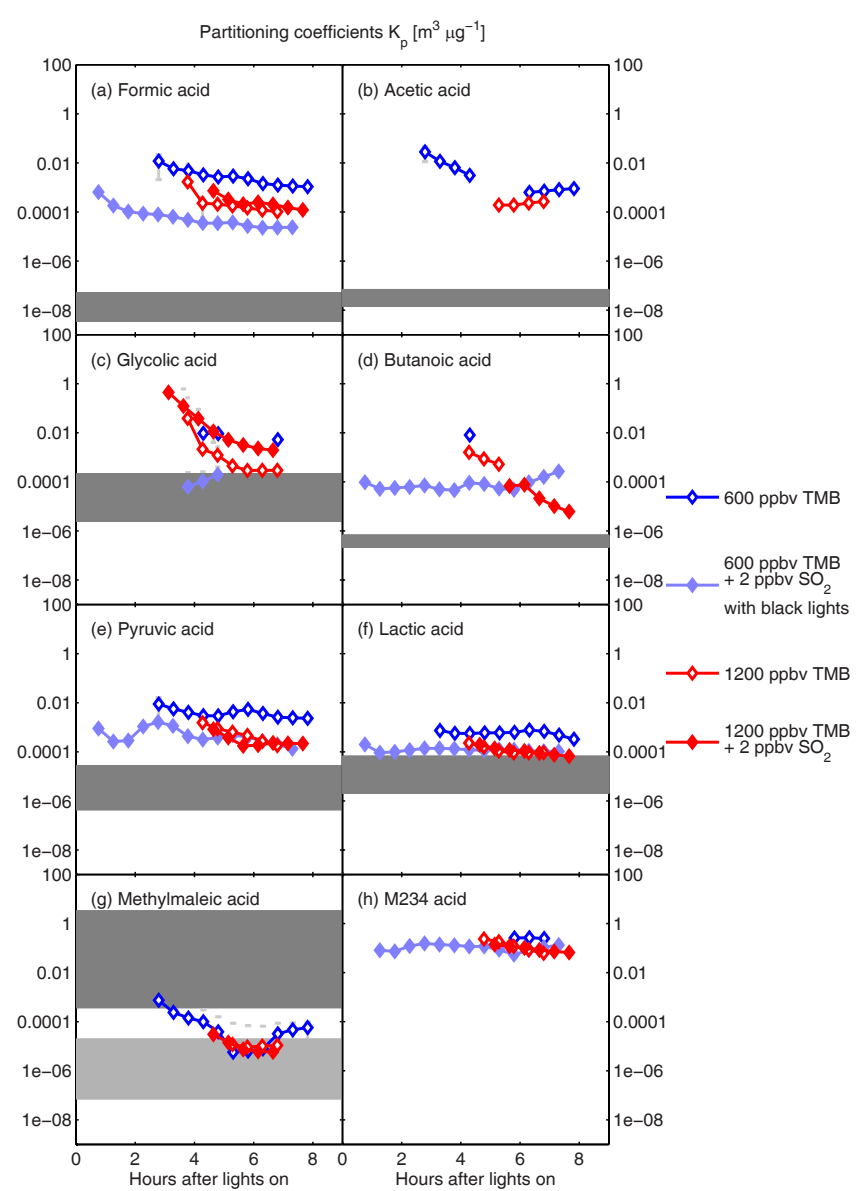

Figure 9. Time-dependent partitioning coefficients, $K_{\mathrm{p}}$ (in $\mathrm{m}^{3} \mu \mathrm{g}^{-1}$ ). Grey areas represent the expected range of values for different saturation vapour pressure estimations. See text for discussion. The lower limit corresponds to the smallest value estimated for $K_{\mathrm{p}}$ and the upper corresponds to the highest effective partitioning

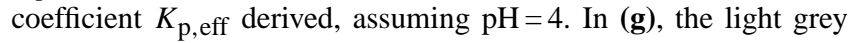
area represents the theoretical value range of methylmaleic anhydride.

experiment. This is very likely due to measurements close to the detection limits in the aerosol phase for these species, so that the decrease mainly reflects the TSP increase in this case.

Aerosol mass spectrometer measurements (not shown) indicate that nitric acid is the main inorganic species present in the aerosol phase and that it is not neutralised by ammonia, whose concentration is much lower. Ammonia was not added deliberately but is an impurity trace gas in the chamber, which has also been determined previously for similar conditions (Kalberer et al., 2004). Therefore, the following discussion holds for these acidic aerosol conditions (assuming $\mathrm{pH}<4$ ).

Sulfuric acid $\left(\mathrm{H}_{2} \mathrm{SO}_{4}\right)$ formed from the oxidation of 2 ppbv $\mathrm{SO}_{2}$ could not be detected by IC/MS. Therefore, the $\mathrm{pH}$ of the aerosol is expected to remain similar in the ex- periments with $\mathrm{SO}_{2}$. In the experiments with $1200 \mathrm{ppbv}$ of TMB, less glycolic acid was detected in the gas phase. For the experiments with $600 \mathrm{ppbv}$ of TMB, $K_{\mathrm{p}}$ values are somewhat lower in the presence of $\mathrm{SO}_{2}$, which is expected from a more acidic aerosol. However, as discussed earlier, it is more likely that $\mathrm{SO}_{2}$ influences the formation of organic acids in the gas phase already, rather than $\mathrm{H}_{2} \mathrm{SO}_{4}$ reducing the $\mathrm{pH}$ of the particle phase.

Figure 9 also depicts estimated ranges of expected $K_{\mathrm{p}}$ values, derived from species vapour pressures $p_{\mathrm{L}}^{0}$ derived from structure-based methods, except for M234, whose structure is unknown. We ran the vapour pressure estimator of the EAIM model and the EVAPORATION method. The outputs were used to estimate $K_{\mathrm{p}}$ and, using $\mathrm{pH}=4$, additional $K_{\mathrm{p} \text {,eff }}$ were estimated (except for methylmaleic anhydride) according to Eq. (4). The plotted ranges cover for each species the largest and lowest values obtained. Overall, the experimental $K_{\mathrm{p}}$ values obtained are much higher than the estimated values.

Weak acids like acetic and butanoic acid are not much affected by this assumption, while the theoretical $K_{\mathrm{p}}$ range for stronger acids like formic, glycolic and lactic acid is increased due to the larger deprotonated acid fraction present in the aerosol at this $\mathrm{pH}$ value. Nevertheless, the discrepancy between the estimated $K_{\mathrm{p}}$ values and the ones experimentally derived remains large, supporting the hypothesis of a measurement artefact or a source of carboxylate ions in the aerosol phase.

Interestingly, the $K_{\mathrm{p}}$ values of methylmaleic acid fall in the range of the theoretical values for methylmaleic anhydride (light grey shaded area). This suggests that no methylmaleic acid (or a negligible amount) is formed in the chamber. It would also indicate that partitioning is not further driven by hydrolysis of the anhydride in the aerosol.

Nevertheless, Healy et al. (2008) found similar results for a wide range of dicarbonyl products, including glyoxal and methylglyoxal. The interpretation given was that reactive uptake as well as oligomerisation reaction in the particle phase takes place, shifting the partitioning to the aerosol, which may also happen with organic acids, via different mechanisms, though. Then, because during sampling in water the oligomers can reverse to their monomeric form, the aerosol concentration is found to be higher than expected.

During the experiment of 10 July 2009, a very large amount of acetic acid $\left(\sim 18 \mathrm{mg} \mathrm{m}^{-3}\right)$ was injected into the chamber after roughly $6 \mathrm{~h}$ of photooxidation. Figure 10 shows that this results in almost no increase of the aerosol phase acetic acid concentration, while according to Henry's law (assuming that the aerosol would take up acetic acid as water would), concentrations between 170 and $2100 \mathrm{ng} \mathrm{m}^{-3}$ would be expected.

This means that the amount of water in the aerosol is too small for reactive uptake. This is another strong indication that the acetic acid (and probably the other volatile organic 


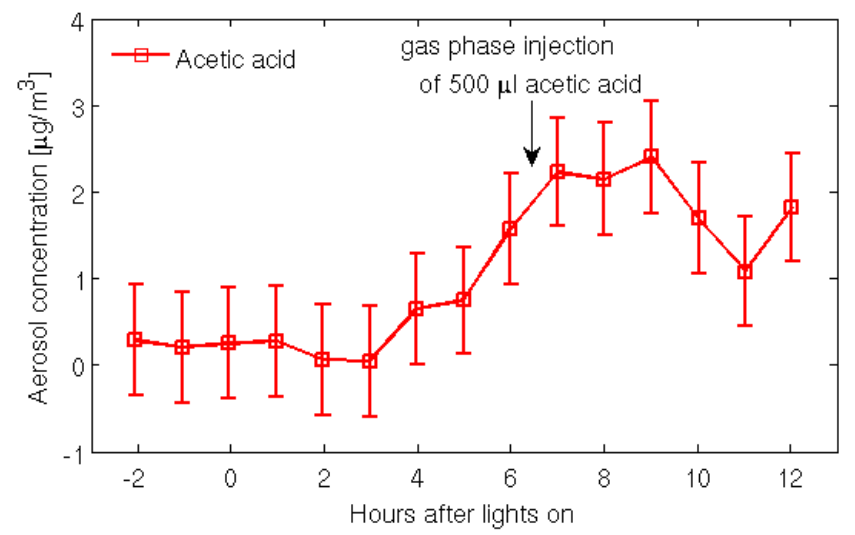

Figure 10. No partitioning of acetic acid onto the aerosol is observed after injection of a large amount of acetic acid.

acids) detected in the particle phase are not due to (enhanced) partitioning, but rather from measurement artefacts.

We assume that their occurrence is the result of the hydrolysis of ester functionalities (formed e.g. by particle phase reactions between organic acids and alcohols; Surratt et al., 2009) during sampling with water.

\section{Summary and conclusions}

Despite the complexity of the chemical composition of photooxidation products from TMB, we were able to selectively separate and detect several organic acids from both gas and aerosol phases with IC/MS. Seven of them could be identified unambiguously. Chemical formulas could be attributed to five additional compounds.

Some of the detected compounds were possibly produced during sampling, like methylmaleic acid, by anhydride hydrolysis or other aqueous reactions. However, many of those compounds are present in low concentration. Therefore, quantitative statements about organic acids in TMB photooxidation have been derived from the one with highest concentrations.

Overall, their fraction represents less than $5 \%$ of SOA after $5 \mathrm{~h}$ of photooxidation in the presence of $\mathrm{SO}_{2}$. In its absence, they represent between 6 and $20 \%$ of the SOA mass.

However, higher partitioning coefficients than predicted by theory were found. As it is not possible to clearly link aerosol acidity with enhanced partitioning into the aerosol phase, this is a strong indication that the method used here may have been influenced by hydrolysis. This indicates that ester oligomers may be present in the aerosol phase and are hydrolysed during sampling with water. Even an injection of a very large amount of additional acetic acid did not significantly increase the amount of acetic acid detected in the aerosol phase. This is a strong indication that it likely arises from hydrolysis of ester functionalities during sampling. For this reason, measurements of $K_{\mathrm{p}}$ with the method presented and possibly others need to be considered with care.

Acknowledgements. We thank the Functional Genomics Centre Zurich and Bertran Gerrits for the opportunity to perform measurements at the Orbitrap XL, René Richter for his help in building the WEDD/AC, Martin Gysel for his support on the SMPS data analysis and Alexander Wokaun for helpful discussions. This work was supported by the Swiss National Science Foundation as well as the EU FP7 project EUROCHAMP-2.

Edited by: A. Laskin

\section{References}

Alfarra, M. R., Paulsen, D., Gysel, M., Garforth, A. A., Dommen, J., Prévót, A. S. H., Worsnop, D. R., Baltensperger, U., and Coe, H.: A mass spectrometric study of secondary organic aerosols formed from the photooxidation of anthropogenic and biogenic precursors in a reaction chamber, Atmos. Chem. Phys., 6, 52795293, doi:10.5194/acp-6-5279-2006, 2006.

Altieri, K., Seitzinger, S., Carlton, A., Turpin, B., Klein, G., and Marshall, A.: Oligomers formed through in-cloud methylglyoxal reactions: Chemical composition, properties, and mechanisms investigated by ultra-high resolution FTICR mass spectrometry, Atmos. Environ., 42, 1476-1490, doi:10.1016/j.atmosenv.2007.11.015, 2008.

Boy, M., Mogensen, D., Smolander, S., Zhou, L., Nieminen, T., Paasonen, P., Plass-Dülmer, C., Sipilä, M., Petäjä, T., Mauldin, L., Berresheim, H., and Kulmala, M.: Oxidation of $\mathrm{SO}_{2}$ by stabilized Criegee intermediate ( $\mathrm{SCI}$ ) radicals as a crucial source for atmospheric sulfuric acid concentrations, Atmos. Chem. Phys., 13, 3865-3879, doi:10.5194/acp-13-3865-2013, 2013.

Calvert, J.: The mechanisms of atmospheric oxidation of aromatic hydrocarbons, Oxford University Press, USA, 2002.

Calvert, J. G. and Madronich, S.: Theoretical study of the initial products of the atmospheric oxidation of hydrocarbons, J. Geophys. Res., 92, 2211-2220, doi:10.1029/JD092iD02p02211, 1987.

Chebbi, A. and Carlier, P.: Carboxylic acids in the troposphere, occurrence, sources, and sinks: A review, Atmos. Environ., 30, 4233-4249, doi:10.1016/1352-2310(96)00102-1, 1996.

Compernolle, S., Ceulemans, K., and Müller, J.-F.: EVAPORATION: a new vapour pressure estimation methodfor organic molecules including non-additivity and intramolecular interactions, Atmos. Chem. Phys., 11, 9431-9450, doi:10.5194/acp-119431-2011, 2011.

Decesari, S., Facchini, M. C., Fuzzi, S., and Tagliavini, E.: Characterization of water-soluble organic compounds in atmospheric aerosol: A new approach, J. Geophys. Res., 105, 1481-1489, doi:10.1029/1999JD900950, 2000.

de Gouw, J. and Warneke, C.: Measurements of volatile organic compounds in the earth's atmosphere using proton-transferreaction mass spectrometry, Mass Spectrom. Rev., 26, 223-257, doi:10.1002/mas.20119, 2007.

Dommen, J., Prevot, A., Baertsch-Ritter, N., Maffeis, G., Longoni, M., Grüebler, F., and Thielmann, A.: High-resolution emission inventory of the Lombardy region: development and com- 
parison with measurements, Atmos. Environ., 37, 4149-4161, doi:10.1016/S1352-2310(03)00507-7, 2003.

Duplissy, J., DeCarlo, P. F., Dommen, J., Alfarra, M. R., Metzger, A., Barmpadimos, I., Prevot, A. S. H., Weingartner, E., Tritscher, T., Gysel, M., Aiken, A. C., Jimenez, J. L., Canagaratna, M. R., Worsnop, D. R., Collins, D. R., Tomlinson, J., and Baltensperger, U.: Relating hygroscopicity and composition of organic aerosol particulate matter, Atmos. Chem. Phys., 11, 1155-1165, doi:10.5194/acp-11-1155-2011, 2011.

Fisseha, R., Dommen, J., Sax, M., Paulsen, D., Kalberer, M., Maurer, R., Höfler, F., Weingartner, E., and Baltensperger, U.: Identification of organic acids in secondary organic aerosol and the corresponding gas phase from chamber experiments, Anal. Chem., 76, 6535-6540, doi:10.1021/ac048975f, 2004.

Gaeggeler, K., Prévót, A. S., Dommen, J., Legreid, G., Reimann, S., and Baltensperger, U.: Residential wood burning in an Alpine valley as a source for oxygenated volatile organic compounds, hydrocarbons and organic acids, Atmos. Environ., 42, 82788287, doi:10.1016/j.atmosenv.2008.07.038, 2008.

Graus, M., Müller, M., and Hansel, A.: High resolution PTR-TOF: quantification and formula confirmation of VOC in real time, J. Am. Soc. Mass Sp., 21, 1037-1044, doi:10.1016/j.jasms.2010.02.006, 2010.

Grossert, J. S., Fancy, P. D., and White, R. L.: Fragmentation pathways of negative ions produced by electrospray ionization of acyclic dicarboxylic acids and derivatives, Can. J. Chem., 83, 1878-1890, doi:10.1139/v05-214, 2005.

Hagen, D. E. and Alofs, D. J.: Linear inversion method to obtain aerosol size distributions from measurements with a differential mobility analyzer, Aerosol Sci. Technol., 2, 465-475, 1983.

Hallquist, M., Wenger, J. C., Baltensperger, U., Rudich, Y., Simpson, D., Claeys, M., Dommen, J., Donahue, N. M., George, C., Goldstein, A. H., Hamilton, J. F., Herrmann, H., Hoffmann, T., Iinuma, Y., Jang, M., Jenkin, M. E., Jimenez, J. L., KiendlerScharr, A., Maenhaut, W., McFiggans, G., Mentel, T. F., Monod, A., Prévót, A. S. H., Seinfeld, J. H., Surratt, J. D., Szmigielski, R., and Wildt, J.: The formation, properties and impact of secondary organic aerosol: current and emerging issues, Atmos. Chem. Phys., 9, 5155-5236, doi:10.5194/acp-9-5155-2009, 2009.

Healy, R. M., Wenger, J. C., Metzger, A., Duplissy, J., Kalberer, M., and Dommen, J.: Gas/particle partitioning of carbonyls in the photooxidation of isoprene and 1,3,5-trimethylbenzene, Atmos. Chem. Phys., 8, 3215-3230, doi:10.5194/acp-8-3215-2008, 2008.

Horie, O., Neeb, P., Limbach, S., and Moortgat, G. K.: Formation of formic acid and organic peroxides in the ozonolysis of ethene with added water vapour, Geophys. Res. Lett., 21, 1523-1526, doi:10.1029/94GL01174, 1994.

Jenkin, M. E., Saunders, S. M., Wagner, V., and Pilling, M. J.: Protocol for the development of the Master Chemical Mechanism, MCM v3 (Part B): tropospheric degradation of aromatic volatile organic compounds, Atmos. Chem. Phys., 3, 181-193, doi:10.5194/acp-3-181-2003, 2003.

Jokinen, T., Sipilä, M., Junninen, H., Ehn, M., Lönn, G., Hakala, J., Petäjä, T., Mauldin III, R. L., Kulmala, M., and Worsnop, D. R.: Atmospheric sulphuric acid and neutral cluster measurements using CI-APi-TOF, Atmos. Chem. Phys., 12, 4117-4125, doi:10.5194/acp-12-4117-2012, 2012.
Kalberer, M., Paulsen, D., Sax, M., Steinbacher, M., Dommen, J., Prevot, A. S. H., Fisseha, R., Weingartner, E., Frankevich, V., Zenobi, R., and Baltensperger, U.: Identification of polymers as major components of atmospheric organic aerosols, Science, 303, 1659-1662, doi:10.1126/science.1092185, 2004.

Kanakidou, M., Seinfeld, J. H., Pandis, S. N., Barnes, I., Dentener, F. J., Facchini, M. C., Van Dingenen, R., Ervens, B., Nenes, A., Nielsen, C. J., Swietlicki, E., Putaud, J. P., Balkanski, Y., Fuzzi, S., Horth, J., Moortgat, G. K., Winterhalter, R., Myhre, C. E. L., Tsigaridis, K., Vignati, E., Stephanou, E. G., and Wilson, J.: Organic aerosol and global climate modelling: a review, Atmos. Chem. Phys., 5, 1053-1123, doi:10.5194/acp-5-1053-2005, 2005.

Kawamura, K., Steinberg, S., and Kaplan, I. R.: Homologous series of C1-C10 monocarboxylic acids and C1-C6 carbonyls in Los Angeles air and motor vehicle exhausts, Atmos. Environ., 34, 4175-4191, doi:10.1016/S1352-2310(00)00212-0, 2000.

Kirkup, L. and Mulholland, M.: Comparison of linear and nonlinear equations for univariate calibration, J. Chromatogr. A, 1029, 1-11, doi:10.1016/j.chroma.2003.12.013, 2004.

Kroll, J. H. and Seinfeld, J. H.: Chemistry of secondary organic aerosol: Formation and evolution of low-volatility organics in the atmosphere, Atmos. Environ., 42, 3593-3624, doi:10.1016/j.atmosenv.2008.01.003, 2008.

Le Breton, M., McGillen, M. R., Muller, J. B. A., Bacak, A., Shallcross, D. E., Xiao, P., Huey, L. G., Tanner, D., Coe, H., and Percival, C. J.: Airborne observations of formic acid using a chemical ionization mass spectrometer, Atmos. Meas. Tech., 5, 30293039, doi:10.5194/amt-5-3029-2012, 2012.

Lim, H.-J., Carlton, A. G., and Turpin, B. J.: Isoprene forms secondary organic aerosol through cloud processing: model simulations, Environ. Sci. Technol., 39, 4441-4446, doi:10.1021/es048039h, 2005.

Madronich, S., Chatfield, R. B., Calvert, J. G., Moortgat, G. K., Veyret, B., and Lesclaux, R.: A photochemical origin of acetic acid in the troposphere, Geophys. Res. Lett., 17, 2361-2364, doi:10.1029/GL017i013p02361, 1990.

Mauldin III, R. L., Berndt, T., Sipilä, M., Paasonen, P., Petäjä, T., Kim, S., Kurtén, T., Stratmann, F., Kerminen, V.-M., and Kulmala, M.: A new atmospherically relevant oxidant of sulphur dioxide, Nature, 488, 193-196, doi:10.1038/nature11278, 2012.

Metzger, A., Dommen, J., Gaeggeler, K., Duplissy, J., Prevot, A. S. H., Kleffmann, J., Elshorbany, Y., Wisthaler, A., and Baltensperger, U.: Evaluation of 1,3,5 trimethylbenzene degradation in the detailed tropospheric chemistry mechanism, MCMv3.1, using environmental chamber data, Atmos. Chem. Phys., 8, 6453-6468, doi:10.5194/acp-8-6453-2008, 2008.

Metzger, A., Verheggen, B., Dommen, J., Duplissy, J., Prévót, A. S. H., Weingartner, E., Riipinen, I., Kulmala, M., Spracklen, D. V., Carslaw, K. S., and Baltensperger, U.: Evidence for the role of organics in aerosol particle formation under atmospheric conditions, P. Natl. Acad. Sci., 107, 6646-6651, doi:10.1073/pnas.0911330107, 2010.

Molina, L. T., Kolb, C. E., de Foy, B., Lamb, B. K., Brune, W. H., Jimenez, J. L., Ramos-Villegas, R., Sarmiento, J., ParamoFigueroa, V. H., Cardenas, B., Gutierrez-Avedoy, V., and Molina, M. J.: Air quality in North America's most populous city overview of the MCMA-2003 campaign, Atmos. Chem. Phys., 7, 2447-2473, doi:10.5194/acp-7-2447-2007, 2007. 
Moller, B., Rarey, J., and Ramjugernath, D.: Estimation of the vapour pressure of non-electrolyte organic compounds via group contributions and group interactions, J. Mol. Liq., 143, 52-63, doi:10.1016/j.molliq.2008.04.020, 2008.

Myrdal, P. B. and Yalkowsky, S. H.: Estimating pure component vapor pressures of complex organic molecules, Ind. Eng. Chem. Res., 36, 2494-2499, doi:10.1021/ie9502421, 1997.

Nannoolal, Y., Rarey, J., Ramjugernath, D., and Cordes, W.: Estimation of pure component properties: Part 1. Estimation of the normal boiling point of non-electrolyte organic compounds via group contributions and group interactions, Fluid Phase Equilib., 226, 45-63, doi:10.1016/j.fluid.2004.09.001, 2004.

Nannoolal, Y., Rarey, J., and Ramjugernath, D.: Estimation of pure component properties: Part 3. Estimation of the vapor pressure of non-electrolyte organic compounds via group contributions and group interactions, Fluid Phase Equilib., 269, 117-133, doi:10.1016/j.fluid.2008.04.020, 2008.

Ng, N. L., Kroll, J. H., Chan, A. W. H., Chhabra, P. S., Flagan, R. C., and Seinfeld, J. H.: Secondary organic aerosol formation from m-xylene, toluene, and benzene, Atmos. Chem. Phys., 7, 3909-3922, doi:10.5194/acp-7-3909-2007, 2007.

Olsen, J. V., Macek, B., Lange, O., Makarov, A., Horning, S., and Mann, M.: Higher-energy C-trap dissociation for peptide modification analysis, Nat. Meth., 4, 709-712, doi:10.1038/nmeth1060, 2007.

Pankow, J. F.: An absorption model of the gas/aerosol partitioning involved in the formation of secondary organic aerosol, Atmos. Environ., 28, 189-193, doi:10.1016/1352-2310(94)900949, 1994a.

Pankow, J. F.: An absorption model of gas/particle partitioning of organic compounds in the atmosphere, Atmos. Environ., 28, 185-188, doi:10.1016/1352-2310(94)90093-0, 1994b.

Paulot, F., Crounse, J. D., Kjaergaard, H. G., Kroll, J. H., Seinfeld, J. H., and Wennberg, P. O.: Isoprene photooxidation: new insights into the production of acids and organic nitrates, Atmos. Chem. Phys., 9, 1479-1501, doi:10.5194/acp-9-1479-2009, 2009.

Paulsen, D., Dommen, J., Kalberer, M., Prévót, A. S. H., Richter, R., Sax, M., Steinbacher, M., Weingartner, E., and Baltensperger, U.: Secondary organic aerosol formation by irradiation of 1,3,5trimethylbenzene- $\mathrm{NO}_{\mathrm{x}}-\mathrm{H}_{2} \mathrm{O}$ in a new reaction chamber for atmospheric chemistry and physics, Env. Sci. Technol., 39, 26682678, doi:10.1021/es0489137, 2005.

Sato, K., Hatakeyama, S., and Imamura, T.: Secondary Organic Aerosol Formation during the photooxidation of Toluene: $\mathrm{NO}_{\mathrm{x}}$ dependance of chemical composition, J. Phys. Chem. A, 111, 9796-9808, doi:10.1021/jp071419f, 2007.

Sato, K., Takami, A., Kato, Y., Seta, T., Fujitani, Y., Hikida, T., Shimono, A., and Imamura, T.: AMS and LC/MS analyses of SOA from the photooxidation of benzene and 1,3,5-trimethylbenzene in the presence of $\mathrm{NO}_{\mathrm{x}}$ : effects of chemical structure on SOA aging, Atmos. Chem. Phys., 12, 4667-4682, doi:10.5194/acp-124667-2012, 2012.

Saunders, S. M., Jenkin, M. E., Derwent, R. G., and Pilling, M. J.: Protocol for the development of the Master Chemical Mechanism, MCM v3 (Part A): tropospheric degradation of nonaromatic volatile organic compounds, Atmos. Chem. Phys., 3, 161-180, doi:10.5194/acp-3-161-2003, 2003.
Saxena, P. and Hildemann, L. M.: Water-soluble organics in atmospheric particles: A critical review of the literature and application of thermodynamics to identify candidate compounds, J. Atmos. Chem., 24, 57-109, doi:10.1007/BF00053823, 1996.

Servant, J., Kouadio, G., Cros, B., and Delmas, R.: Carboxylic monoacids in the air of Mayombe forest (Congo): Role of the forest as a source or sink, J. Atmos. Chem., 12, 367-380, doi:10.1007/BF00114774, 1991.

Stein, S. E. and Brown, R. L.: Estimation of normal boiling points from group contributions, J. Chem. Inf. Comput. Sci., 34, 581587, doi:10.1021/ci00019a016, 1994.

Surratt, J. D., Chan, A. W. H., Eddingsaas, N. C., Chan, M., Loza, C. L., Kwan, A. J., Hersey, S. P., Flagan, R. C., Wennberg, P. O., and Seinfeld, J. H.: Reactive intermediates revealed in secondary organic aerosol formation from isoprene, P. Natl. Acad. Sci., 107, 6640-6645, doi:10.1073/pnas.0911114107, 2009.

Takeuchi, M., Li, J., Morris, K. J., and Dasgupta, P. K.: Membranebased parallel plate denuder for the collection and removal of soluble atmospheric gases, Anal. Chem., 76, 1204-1210, doi:10.1021/ac0348423, 2004.

Takeuchi, M., Ullah, S. M. R., Dasgupta, P. K., Collins, D. R., and Williams, A.: Continuous collection of soluble atmospheric particles with a wetted hydrophilic filter, Anal. Chem., 77, 80318040, doi:10.1021/ac051539o, 2005.

Vega, E., Sánchez-Reyna, G., Mora-Perdomo, V., Iglesias, G. S., Arriaga, J. L., Limón-Sánchez, T., Escalona-Segura, S., and Gonzalez-Avalos, E.: Air quality assessment in a highly industrialized area of Mexico: Concentrations and sources of volatile organic compounds, Fuel, 90, 3509-3520, doi:10.1016/j.fuel.2011.03.050, 2011.

Veres, P. R., Roberts, J. M., Cochran, A. K., Gilman, J. B., Kuster, W. C., Holloway, J. S., Graus, M., Flynn, J., Lefer, B., Warneke, C., and Gouw, J. d.: Evidence of rapid production of organic acids in an urban air mass, Geophys. Res. Lett., 38, L17807, doi:10.1029/2011GL048420, 2011.

Welz, O., Savee, J. D., Osborn, D. L., Vasu, S. S., Percival, C. J., Shallcross, D. E., and Taatjes, C. A.: Direct kinetic measurements of Criegee intermediate $\left(\mathrm{CH}_{2} \mathrm{OO}\right)$ formed by reaction of $\mathrm{CH}_{2} \mathrm{I}$ with $\mathrm{O}_{2}$, Science, 335, 204-207, doi:10.1126/science.1213229, 2012.

Williams, B. J., Goldstein, A. H., Millet, D. B., Holzinger, R., Kreisberg, N. M., Hering, S. V., White, A. B., Worsnop, D. R., Allan, J. D., and Jimenez, J. L.: Chemical speciation of organic aerosol during the International Consortium for Atmospheric Research on Transport and Transformation 2004: Results from in situ measurements, J. Geophys. Res., 112, D10S26, doi:10.1029/2006JD007601, 2007.

Wyche, K. P., Monks, P. S., Ellis, A. M., Cordell, R. L., Parker, A. E., Whyte, C., Metzger, A., Dommen, J., Duplissy, J., Prevot, A. S. H., Baltensperger, U., Rickard, A. R., and Wulfert, F.: Gas phase precursors to anthropogenic secondary organic aerosol: detailed observations of 1,3,5-trimethylbenzene photooxidation, Atmos. Chem. Phys., 9, 635-665, doi:10.5194/acp-9-635-2009, 2009. 